\title{
Senna alata (akapulko) Extract versus Topical Antifungals for Treatment of Superficial Fungal Skin Infections: a Systematic Review and Meta-analysis
}

\author{
Erin Jane L. Tababa, ${ }^{1}$ Rowena Natividad S. Flores-Genuino ${ }^{2}$ and Charissa Mia D. Salud-Gnilo ${ }^{1}$ \\ ${ }^{1}$ Section of Dermatology, Department of Medicine, College of Medicine and Philippine General Hospital, University of the Philippines Manila \\ ${ }^{2}$ Department of Anatomy, College of Medicine, University of the Philippines Manila
}

\begin{abstract}
Objective. The study aimed to assess the efficacy and safety of Senna alata (akapulko) plant extracts compared with topical antifungals in the treatment of superficial fungal skin infections.

Methods. A systematic review and meta-analysis of randomized controlled trials that studied patients with diagnosed cutaneous tinea or dermatophytosis (excluding hair and nail), tinea versicolor, or cutaneous candidiasis, via microscopy or culture, and compared the efficacy and safety of S. alata (akapulko) extract versus topical antifungals. Two authors independently screened titles and abstracts of merged search results from electronic databases (The Cochrane Skin Group Specialized Register, CENTRAL, MEDLINE, EMBASE (January 1990 to December 2011), Health Research and Development Information Network (HERDIN), and reference lists of articles), assessed eligibility, assessed the risk of bias using the domains in the Cochrane Risk Bias tool and collected data using a pretested Data extraction form (DEF). Meta-analyses were performed when feasible.
\end{abstract}

Results. We included seven RCTs in the review. There is low certainty of evidence that S. alata $50 \%$ lotion is as efficacious as sodium thiosulfate $25 \%$ lotion (RR $0.91,95 \% \mathrm{Cl}, 0.79$ to $1.04 ; 4 \mathrm{RCTs}, \mathrm{n}=216 ; \mathrm{p}=0.15 ; \mathrm{I}^{2}=52 \%$ ) and high quality evidence that $S$. alata cream is as efficacious as ketoconazole (RR $0.95,95 \% \mathrm{Cl}, 0.82$ to $1.09 ; 1 \mathrm{RCT}$, $\mathrm{n}=40 ; \mathrm{p}=0.44$ ) and terbinafine cream (RR 0.93, 95\% Cl, 0.86 to $1.01 ; 1 \mathrm{RCT}, \mathrm{n}=150 ; \mathrm{p}=0.09$ ) in mycologic cure. For adverse effects, there is very low certainty of evidence of increased harm with $\mathrm{S}$. alata $50 \%$ lotion compared to sodium thiosulfate $25 \%$ lotion (RR $1.26,95 \% \mathrm{Cl}, 0.46,3.44 ; 2 \mathrm{RCTs}, \mathrm{n}=120 ; \mathrm{p}=0.65 ; \mathrm{I}^{2}=19 \%$ ). Adverse effects were few and mild.

Conclusion. S. Alata $50 \%$ lotion may be as efficacious as sodium thiosulfate $25 \%$ lotion and is as efficacious as ketoconazole $2 \%$ and terbinafine $1 \%$ creams. There is insufficient evidence to compare the safety of S. alata $50 \%$ lotion with sodium thiosulfate $25 \%$ lotion.

Key Words: Senna alata, Cassia alata, akapulko, skin fungal infections, dermatophytosis, tinea versicolor, pityriasis versicolor, candidiasis, systematic review, meta-analysis.

\section{INTRODUCTION}

Corresponding author: Erin Jane L. Tababa, MD

Section of Dermatology

Department of Medicine

Philippine General Hospital

University of the Philippines Manila

Taft Avenue, Manila 1000, Philippines

Email: erintababa@gmail.com
Superficial fungal skin infections are prevalent in tropical countries, and are commonly caused by pathogenic dermatophytes (Trichophyton spp., Epidermophyton spp., and Microsporum spp.), and normal skin commensals such as Malassezia spp. and Candida albicans. Dermatophytes are keratinase-producing fungi that are capable of invading and reproducing within the keratinized tissue of hair, nails, and skin. ${ }^{1}$ These may be transmitted via contact with infected 
Akapulko for the Treatment of Superficial Fungal Infections

humans, animals, or through exposure with contaminated soil. ${ }^{2}$ Tinea versicolor (also known as pityriasis versicolor) is caused by lipophilic Malassezia yeasts, which are normal skin commensals. ${ }^{3}$ Candida albicans is also part of the normal flora of the skin, but may cause cutaneous candidiasis particularly in immunocompromised individuals. ${ }^{4}$,

Dermatophytosis, particularly tinea corporis, is one of the 10 most common skin conditions at the Philippine General Hospital's Section of Dermatology. Based on the Health Information System of the Philippine Dermatological Society last 2017, dermatophytosis is the $2^{\text {nd }}$ most common diagnosis seen among both new and old patients..$^{5}$ It is extremely pruritic, highly contagious, and the treatment can be lengthy and costly. Tinea versicolor is usually asymptomatic; however, the skin discoloration and highly recurrent course pose cosmetic concerns for the patient. Lastly, although candidiasis is rarely associated with significant morbidity in healthy hosts, it may become persistent and disseminate systemically in immunocompromised individuals. ${ }^{6}$

There are several treatment options for tinea versicolor and dermatophytosis. These include keratolytic agents like selenium sulfide, propylene glycol, and salicylic acid, which act by facilitating removal of affected skin. ${ }^{7}$ Drugs that work by inhibiting the cytochrome p450-dependent conversion of lanosterol to ergosterol, such as sodium thiosulfate and ketoconazole, disrupt fungal cell membrane and subsequent leakage of cellular contents. ${ }^{8}$ Terbinafine, an allylamine, inhibits squalene epoxidase, the enzyme necessary for the conversion of squalene to lanosterol, thus preventing synthesis of ergosterol. ${ }^{2}$

Senna alata (L.) Roxb. (syn. Cassia alata) (family Leguminosae/Fabaceae) or candle bush is an indigenous plant of central America and known in the Philippines as akapulko. ${ }^{9} S$. alata has long been purported to have antifungal property and has been studied in several clinical trials regarding its effect on superficial fungal infections such as dermatophytosis and tinea versicolor. ${ }^{10-14}$ In vitro studies showed that crude methanol and ethanol extracts of $S$. alata, inhibit growth of Trichophyton rubrum, Microsposrum canis, and Candida albicans. ${ }^{15,16}$ According to an in vitro study, anthraquinone aglycones and anthraquinone aglycosides, identified through thin layer chromatography of crude ethanol extracts, are responsible for $S$. alata's antifungal activity. ${ }^{17}$

S. alata is one of the ten medicinal plants approved for use by the Philippines' Department of Health. The plant is readily accessible throughout the Philippines, commonly known to the layperson as a household treatment for skin fungal diseases, and a cheaper alternative to the more costly azoles and allylamines (leading drugstore, $93 \mathrm{php}$ per 15 gram tube). ${ }^{18,19}$ Although there are numerous studies available, treatment effects are uncertain. A systematic review was done in order to collate existing data regarding efficacy and safety of $S$. alata as an antifungal.

\section{OBJECTIVE}

This review aimed to assess $S$. alata's efficacy and safety compared with other topical antifungal drugs as treatment for superficial fungal infections.

\section{METHODS}

The Cochrane Collaboration methods ${ }^{20}$ and the PRISMA ${ }^{21}$ statement were followed in this systematic review.

\section{Data Sources}

The authors conducted a search of electronic databases (from inception to September 2014), namely: Cochrane Skin Group Specialized Register, Cochrane Central Register of Controlled Trials (CENTRAL), EMBASE, MEDLINE, and Health Research and Development Information Network (HERDIN). We searched for unpublished trials and ongoing trials using ClinicalTrials.gov and contacted authors and organizations. We also searched grey literature, references of included studies, and hand-searched relevant journals (Journal of the Philippine Dermatological Society 19922013) for potential studies. The following search terms were used "Senna alata," "Cassia alata," "senna," "cassia," "akapulko," dermatophyt", tinea, candidiasis, moniliasis, and candida. All relevant randomized controlled trials regardless of language and status of publication were included.

Two authors (RG, ET) independently assessed the titles and abstracts of retrieved trials from the search for eligibility for inclusion in the review. When the titles and abstracts were not enough to decide on eligibility of the trial, the full report was retrieved to make a decision. If information in full report is still not complete, the author was contacted to clarify unclear items. A single failed eligibility criterion was enough to exclude the trial. Disagreements were resolved by discussion.

\section{Study Selection}

We included all relevant RCTs regardless of language, and status of publication that compared S. alata extract, from any part of the plant, with allylamines, azoles, or nonspecific antifungals as treatment for patients with diagnosed dermatophytosis, cutaneous candidiasis or tinea versicolor via direct microscopy. Only the first phase of cross-over RCTs was included. We excluded studies involving other species of Senna and studies with other components combined with S. alata extract. Trials were included if they reported the following primary outcomes: percentage of participants with mycologic clearance defined as a negative $\mathrm{KOH}$ mount, and percentage of participants who develop adverse/side effects to treatment. Secondary outcome measures were percentage of participants with clinical resolution of lesions as evaluated by outcome assessor, and percentage of participants who reported clinical resolution of symptoms. 


\section{Data Extraction and Quality Assessment}

Two reviewers independently extracted data using a pretested data extraction form, and assessed risk of bias using the Cochrane Collaboration Risk of Bias tool ${ }^{20}$ from the included studies. Disagreements between the two authors were resolved through discussion or a third author. Original authors of study reports were contacted to ask details of missing data or items needing clarification.

Data was pooled for studies which were clinically homogenous. RevMan 5 was used to generate summary tables and graphs. For dichotomous outcomes, risk ratio and $95 \%$ confidence intervals were used, while for continuous outcomes, mean difference and SD were used. We attempted to do intent-to-treat analysis by analyzing non-compliant participants or protocol violators in the group they were randomized to, regardless of how the original authors analyzed them. Missing data (e.g., participants lost to followup who did not have any outcome assessments at relevant time points) were excluded from the main analysis (available case analysis).

Heterogeneity was assessed using visual inspection of the forest plots to check for overlapping confidence intervals. We also computed for chi-square test for heterogeneity at $10 \%$ level of significance, and $\mathrm{I}^{2}$ statistic was also computed. If $\mathrm{I}^{2}$ value was $>50 \%$, heterogeneity was assessed to be significant, and if $>75 \%$, it was assessed to be substantial. If significant heterogeneity existed, random effects model was used; otherwise, fixed effects model was used. When significant heterogeneity existed, subgroup analysis was done to determine the possible cause of heterogeneity.

\section{RESULTS}

Out of 119 records via database searching and 3 additional records via hand searching, 59 duplicates were excluded, leaving 63 records for screening of titles and abstracts. After assessing full reports and abstracts of nine potentially relevant studies for eligibility, two studies were excluded (Appendix 1) and seven studies were included in qualitative and quantitative analyses (Figure 1).

The seven included studies are described in Appendix 2. Four RCTs (461 patients) compared S. alata 50\% lotion versus sodium thiosulfate (STS) $25 \%$ lotion as treatment for tinea versicolor. ${ }^{10,11,14,22}$ One study (150 patients) compared $S$. alata cream of unknown concentration against $1 \%$ terbinafine cream as treatment for tinea versicolor. ${ }^{23}$ One study (48 patients) investigated an unknown concentration of $S$. alata cream against ketoconazole cream as treatment for cutaneous fungal infections and tinea versicolor. ${ }^{13}$ One study was conducted in a prison (67 inmates) and compared 3 different kinds of herbal soaps with antifungal properties ( $3 \%$ S. alata soap; 5\% Erythrophleum guineense; 5\% Aframomum melegueta + Pipers guineense + Xylopia aethiopica) to treat tinea versicolor, tinea corporis, scabies, and acne/"bump". ${ }^{24}$ We did not identify any trials on $S$. alata for cutaneous candidiasis.

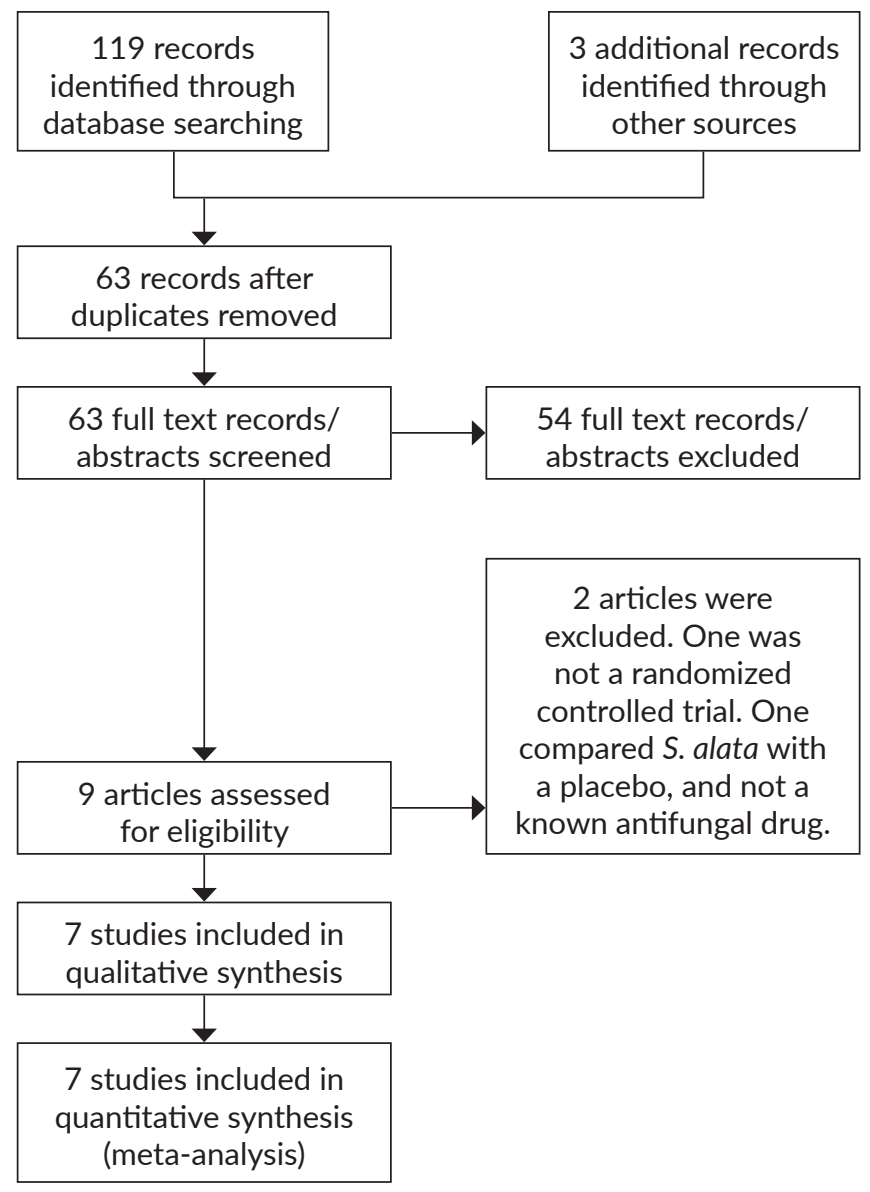

Figure 1. Study flowchart.

Overall quality assessment shows that majority of studies were low risk for bias for all domains except for selective reporting domain where majority were moderate to high risk of reporting bias due to unclear or different definition of cure outcomes (Figure 2).

Only three studies had at least one domain with high risk of bias (Figure 3).

\section{Primary Outcome Measures}

\section{Mycologic cure}

Four trials that compared S. alata 50\% lotion with STS $25 \%$ lotion showed that the two treatments were equally efficacious for mycologic cure in tinea versicolor (RR 0.91, 95\% CI, 0.79, 1.04; $\mathrm{p}=0.15$ ) (Figure 4). ${ }^{10,11,14,22}$ The presence of significant heterogeneity $\left(\mathrm{I}^{2}=52 \%\right)$ may be attributed to a longer treatment period, and significant number of dropouts in one study. ${ }^{22}$

Two individual studies noted no significant difference in mycologic cure comparing $S$. alata cream with ketoconazole cream as treatment for dermatophytosis or tinea versicolor (RR 0.95, 95\% CI 0.82, 1.09; $n=40 ; p=0.44)^{13}$ and terbinafine $1 \%$ cream when applied twice daily for two weeks (RR 0.93 , $95 \%$ CI, 0.86, 1.01; $\mathrm{n}=150 ; \mathrm{p}=0.09) .{ }^{23}$ 


\section{Adverse effects}

Only two studies that compared S. alata 50\% lotion with STS 25\% lotion as treatment for tinea versicolor noted adverse effects. ${ }^{10,14}$ We were uncertain if $S$. alata lotion had more adverse effects than STS lotion (RR 1.26, 95\% CI $0.46,3.44 ; 2 \mathrm{n}=120 ; \mathrm{p}=0.65 ; \mathrm{I}^{2=19 \%}$ ) (Figure 5). ${ }^{10,14}$ The most common adverse effect for both treatments was pruritus. No adverse effects were reported by participants in the study which compared S. alata cream with ketoconazole cream as treatment for dermatophytosis or tinea versicolor, and in the study comparing S. alata cream with $1 \%$ terbinafine cream as treatment for tinea versicolor. ${ }^{13,23}$

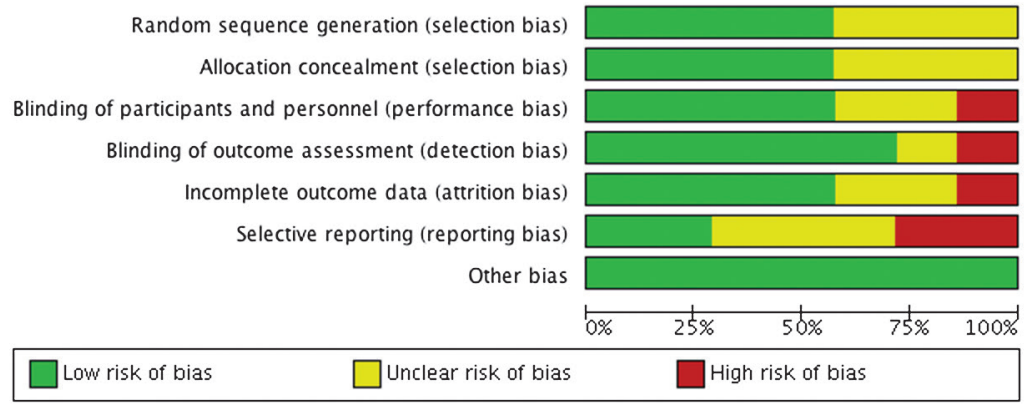

Figure 2. Risk of bias graph showing authors' judgments about risk of bias item across all included studies.

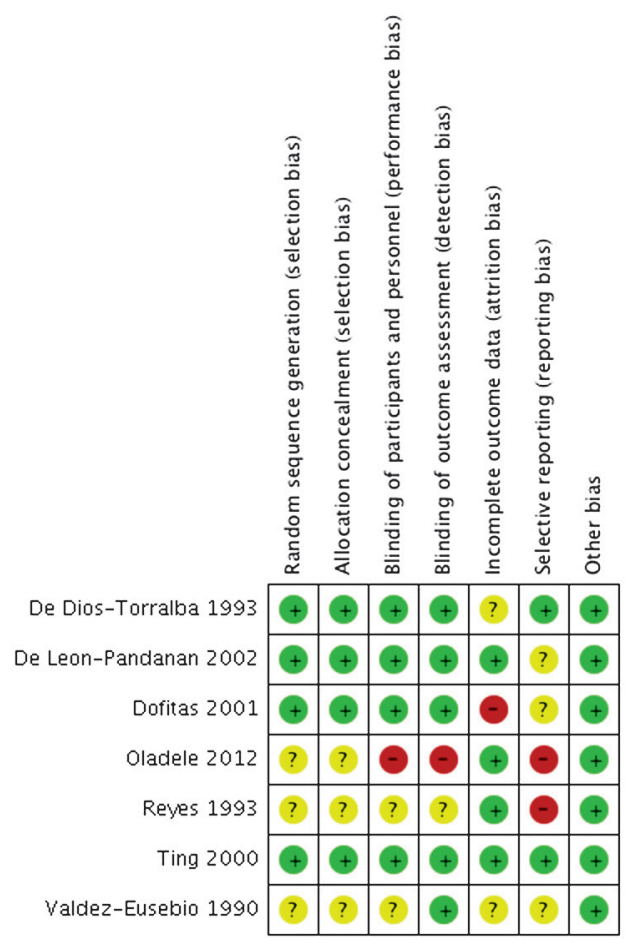

Figure 3. Risk of bias summary showing authors' judgments about each risk of bias item for each included study.

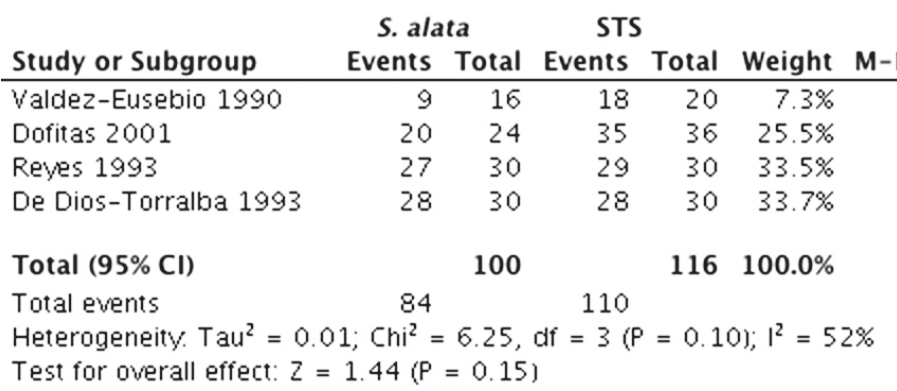

Risk Ratio $0.63[0.40,0.99]$ $0.86[0.71,1.03]$ $0.93[0.81,1.07]$ $1.00[0.87,1.14]$

$0.91[0.79,1.04]$

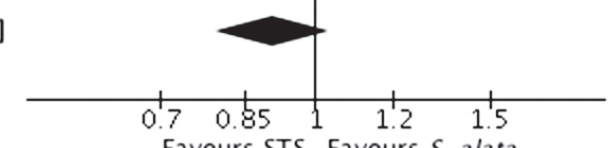

Favours STS Favours S. alata

Figure 4. S. alata 50\% lotion versus STS 25\% lotion, Outcome: Mycologic cure.

\begin{tabular}{|c|c|c|c|c|c|c|c|c|}
\hline Study or Subgroup & \multicolumn{2}{|c|}{ S. alata } & \multicolumn{2}{|c|}{ Sodium Thiosulfate } & Weight & $\begin{array}{c}\text { Risk Ratio } \\
\text { M-H, Random, } 95 \% \mathrm{CI}\end{array}$ & $\begin{array}{c}\text { Risk Ratio } \\
\mathbf{M}-\mathbf{H}, \text { Random, } 95 \% \mathrm{CI}\end{array}$ & \\
\hline De Dios-Torralba 1993 (1) & 7 & 30 & 4 & 30 & $80.7 \%$ & $1.75[0.57,5.36]$ & \begin{tabular}{l|l}
+2 \\
-1
\end{tabular} & \\
\hline Dofitas $2001(2)$ & 0 & 24 & 2 & 36 & $19.3 \%$ & $0.30[0.01,5.91]$ & & \\
\hline Total $(95 \% \mathrm{Cl})$ & & 54 & & 66 & $100.0 \%$ & $1.24[0.31,5.03]$ & & \\
\hline Total events & 7 & & 6 & & & & & \\
\hline $\begin{array}{l}\text { Heterogeneity. } \mathrm{Tau}^{2}=0.30 \\
\text { Test for overall effect: } z=0\end{array}$ & $\begin{array}{l}\mathrm{Chi}^{2}=1 \\
30(\mathrm{P}=0\end{array}$ & $\begin{array}{l}23, \mathrm{df} \\
.76 \mathrm{~J}\end{array}$ & $=1(P=0.2$ & $=19 \%$ & & & 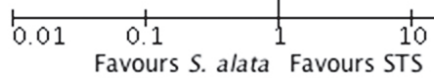 & 100 \\
\hline
\end{tabular}

Footnotes

(1) Akapulko - $6 \mathrm{w} /$ pruritus, $1 \mathrm{w} /$ transient burning sensation; STS $-4 \mathrm{w} /$ pruritus

(2) STS - $2 \mathrm{w} /$ transient erythema and pruritus

Figure 5. S. alata lotion versus STS 25\% lotion, Outcome: Adverse effects. 


\section{Secondary Outcomes}

\section{Clinical resolution (as reported by outcome assessors)}

One study ( $\mathrm{n}=36$ ) noted $S$. alata $50 \%$ lotion to be less efficacious in clinical resolution of tinea versicolor than STS $25 \%$ lotion (RR $0.63,95 \%$ CI 0.40, 0.99; $\mathrm{p}=0.04$ ). ${ }^{10}$ In one other study, it was uncertain whether S. alata cream was less efficacious than ketoconazole cream (RR 0.37, 95\% CI $0.02,8.5 ; n=40 ; p=0.53$ ) in achieving complete clearance of lesions of dermatophytosis and tinea versicolor. ${ }^{13}$

One study compared $S$. alata soap with two antifungal soaps (Erythrophleum soap and Aframomum soap) in patients diagnosed with either tinea versicolor or tinea corporis. It was uncertain whether $S$. alata soap was more efficacious than Erythrophleum soap (RR 1.15, 95\% CI 0.65, 2.06; n=35; $\mathrm{p}=0.63$ ), but there was a trend that it was more efficacious than Aframomum soap (RR 1.94, 95\% CI 0.91, 4.13; $\mathrm{n}=37$; $\mathrm{p}=0.09) .{ }^{24}$

\section{DISCUSSION}

This review included seven RCTs with 460 participants, mostly patients with tinea versicolor, done in the Philippines (5/7), medium-sized (median sample size $=98$ ), and conducted in the 1990s to 2000s (6/7). The paucity of RCTs using $S$. alata is quite striking considering that it is one of the ten medicinal plants recommended by the Department of Health in the Philippines. Four of the seven included trials used STS lotion as control. The World Health Organization lists sodium thiosulfate as one of the topical treatments for tinea versicolor. ${ }^{25}$ It acts as a keratolytic, enabling the removal of stratum corneum affected by dermatophytes, and as a fungistatic, particularly against Malassezia furfur, but its mechanism is unknown. ${ }^{26,27} \mathrm{Of}$ note, current guidelines (NICE, UpToDate) and textbooks recommend topical antifungals such as azoles, allylamines, selenium sulfide, and zinc pyrithione as treatment for superficial fungal infections. ${ }^{2,28,29}$ Although the goal of this review is to determine the efficacy of $S$. alata against superficial fungal infections, majority of the studies focused on tinea versicolor, which is caused by yeasts. In addition, only two, small-sized studies compared $S$. alata with established antifungals: ketoconazole and terbinafine.

There is low certainty of evidence that $S$. alata is as effective as STS 25\% lotion for mycologic cure (RR 0.91, 95\% CI 0.79 to $1.04 ; 4$ RCTs, $n=216$ ) but less effective for clinical cure (RR $0.63,95 \%$ CI 0.40 to $0.99,1$ RCT, $\mathrm{n}=36$ ) (Appendix 3: Summary of Findings Table 1). The evidence was downgraded due to a high risk for attrition bias, as well as high heterogeneity between studies probably since one study had a longer treatment period. In terms of adverse effects, there is very low certainty of evidence that S. alata has greater risk of harm than STS 25\% lotion (RR $1.26,95 \%$ CI 0.46 to $3.44 ; 2$ RCTs, $n=120 ; I^{2=19 \%) . ~ T h e ~}$ evidence was downgraded twice due to the high risk of bias (because of high attrition rate) and imprecision due to small sample size.

There is high certainty of evidence that $S$. alata is as efficacious as terbinafine for mycologic cure (RR 0.93, 95\% CI 0.86 to $1.01 ; 1 \mathrm{RCT}, \mathrm{n}=150$ ) (Appendix 3: Summary of Findings Table 2) There is high certainty of evidence that $S$. alata is as efficacious as ketoconazole for mycologic cure (RR $0.95,95 \%$ CI 0.82 to $1.09,1 \mathrm{RCT}, \mathrm{n}=40$ ) but low certainty of evidence that it is less efficacious for clinical cure (RR 0.37, 95\% CI 0.02 to 8.5; 1 RCT, n=40) (Appendix 3: Summary of Findings Table 3.

Lastly, there is very low certainty of evidence that $S$. alata soap is as efficacious as Erythrophleum soap (RR 1.15, 95\% CI 0.65 to $2.06 ; 1 \mathrm{RCT}, \mathrm{n}=35$ ), and more efficacious than Aframomum soap (RR 1.94, 95\% CI 0.91 to $4.13 ; 1 \mathrm{RCT}$, $\mathrm{n}=37$ ) for mycologic cure. The evidence was downgraded twice due to significant risk of bias from lack of blinding of participants and personnel, lack of pre-specified objectives or outcomes, and a high number of dropouts.

\section{CONCLUSIONS}

This review suggests that $S$. alata lotion may be as efficacious as STS 25\% lotion in the treatment of tinea versicolor. Adverse effects were few and mild for both treatments and it is unclear whether there is a risk for greater adverse effects due to $S$. alata lotion. Based on single studies, S. alata lotion may be as efficacious as terbinafine and ketoconazole creams.

\section{Implications for research}

There is a need for more adequately-sized RCTs with good follow-up comparing $S$. alata with standard topical antifungal drugs in the treatment of tinea versicolor, cutaneous dermatophyte infections, and candidiasis.

\section{Ethics review approval}

University of the Philippines-Philippine General Hospital (UP-PGH) Expanded Hospital Research Office (EHRO), October 2015 (2015-10-07-058)

\section{Study registration}

UP Manila-Research Grants Administration Office, January 2018 (RGAO-2018-0014)

\section{Statement of Authorship}

All authors participated in data collection and analysis, and approved the final version submitted.

\section{Author Disclosure}

All authors declared no conflict of interest.

\section{Funding Source}

This paper was self-funded. 


\section{REFERENCES}

1. Weitzman I, Summerbell RC. The dermatophytes. Clin Microbiol Rev. 1995; 8(2):240-59

2. Bolognia JL, Jorizzo JL, Schaffer JV. Dermatology, 3rd ed [Internet]. Elsevier Health Sciences; 2012 [cited 2015 Oct]. Available from https://books.google.com/books?id=A78BaiEKnzIC\&pgis=1.

3. Goldsmith L, Katz S, Gilchrest B, Paller A, Leffell D, Wolff K. Superficial Fungal Infection. In: Fitzpatrick's Dermatology in General Medicine, Eighth Edition [Internet]. McGraw Hill Professional; 2012 [cited 2015 Jul]:1376. Available from https://books.google.com/ books?id=OccI1HZFhZoC\&pgis=1.

4. Evans CC, High WA. Skin Diseases in the Elderly: A Color Handbook [Internet]. CRC Press; 2011 [cited 2015 Oct]. Available from https://books.google.com/books?id=fPMoxcB2XDwC\&pgis=1.

5. Health Information Systems Task Force-Philippine Dermatological Society. Top Ten Diagnosis [Internet]. 2017 [cited 2015 Sep]:2. Available from https://mail.google.com/mail/u/0/\#inbox/16168210ba a54de6? projector $=1 \&$ messagePartId $=0.1$.

6. Georgiev V St. Infectious Diseases in Immunocompromised Hosts [Internet]. CRC Press; 1997 [cited 2015 Oct]. Available from https://books.google.com/books?id=73QOP6Xqh6EC\&pgis=1.

7. Maibach HI, Gorouhi F. Evidence Based Dermatology [Internet]. PMPH-USA; 2011 [cited 2015 Oct]. Available from https://books.google.com/books?id=V2L1MAoGHVkC\&pgis=1.

8. Groll AH, Kolve H. Antifungal agents: In vitro susceptibility testing, pharmacodynamics, and prospects for combination therapy. Eur J Clin Microbiol Infect Dis. 2004;23(4):256-70. doi:10.1007/s10096-0041108-6

9. Clay HF, Hubbard JC, Golt R. Tropical Shrubs [Internet]. University of Hawaii Press; 1987 [cited 2015 Oct]. Available from https://books.google.com/books?id=692L-8HWiEsC\&pgis=1.

10. Dofitas BL, Chan B, Reyes R, Guloy N, Maramba N. A randomized controlled trial on the efficacy and safety of $50 \%$ Akapulko lotion compared with $25 \%$ Sodium thiosulfate lotion among patients with Tinea versicolor. J Phil Dermatol Soc. 2001; 10(1):10-6.

11. Paz-Reyes R, Guloy NG, Maramba NC. Phase II: Efficacy and safety of $50 \%$ akapulko lotion compared to placebo and $25 \%$ sodium thiosulfate among patients with tinea versicolor: a double-blind randomized controlled trial. In: Akapulko Technology Transfer Document. 1993; 82-83.

12. Dofitas BL. A randomized controlled trial on the efficacy and safety of 50 percent akapulko lotion compared with 25 percent sodium thiosulfate lotion among patients with tinea versicolor. J Phil Dermatol Soc. 2001; 10(1):10-6.

13. Ting MG. A comparative study on the efficacy of Akapulko (Cassia alata, Linn.) cream versus topical ketoconazole in the treatment of cutaneous fungal infection: a randomized controlled double blind clinical trial. 2000. Unpublished.

14. de Dios-Torralba L, Alora MBT. Phase III Clinical Trial (UST): Efficacy and Safety of 50\% Akapulko Lotion Compared to 25\% Sodium Thiosulfate among Patients with Tinea Versicolor; A Double Blind Randomized Controlled Clinical Trial. In: Akapulko Technology Transfer Document [Internet]. ; 1993 [cited 2015 Jul];86-88. Available from http://www.geocities.ws/fzg37/s_phase2_akapulko2_ abstract.htm.

15. Abubacker MN, Ramanathan R, Senthil Kumar T. In vitro antifungal activity of Cassia alata Linn. flower extract. Nat Prod Radiance. 2008; 7(1):6-9.

16. Sule WF, Okonko IO, Joseph TA, Ojezele MO, Nwanze JC, Alli JA, et al. In vitro antifungal activity of Senna alata Linn. crude leaf extract. Res J Biol Sci. 2010; 5(3):275-84. doi:10.3923/rjbsci.2010.275.284
17. Wuthi-udomlert M, Kupittayanant P, Gritsanapan W. In vitro evaluation of antifungal activity of anthraquinone derivatives of Senna alata. J Health Res. 2010; 24(3):117-22.

18. Philippine National Herbarium. Senna alata (L.) [Internet]. 2014 [cited 2017 Nov]. Available from http://www.nationalmuseum.gov.ph/ nationalmuseumbeta/Collections/Botany/Senna.html. P

19. Department of Health. The Philippine Drug Price Reference Index [Internet]. 2016 [cited 2017 Nov]. Available from http://www.dpri. doh.gov.ph/download/2016 DPRI Fourth Edition.pdf.

20. Higgins JPT, Green S (Sally E, Cochrane Collaboration., Wiley InterScience (Online service). Cochrane Handbook for Systematic Reviews of Interventions [Internet]. Wiley-Blackwell; 2008 [cited 2017 Oct].Available from https://books.google.com/books/about/Cochrane_ Handbook_for_Systematic_Reviews.html?id=NKMg9sMM6GUC\& printsec=frontcover\&source=kp_read_button\# $\mathrm{v}=$ onepage\&q\&f=false.

21. Moher D, Liberati A, Tetzlaff J, Altman DG, PRISMA Group. Preferred reporting items for systematic reviews and meta-analyses: the PRISMA statement. BMJ. 2009;339:b2535. doi:10.1136/BMJ.B2535

22. Valdez-Eusebio J, Teodosio GB, Maramba NC. Efficacy and safety of $50 \%$ akapulko lotion compared to placebo and $25 \%$ sodium thiosulfate among patients with Tinea Versicolor: a double-blind randomized controlled trial.In: Akapulko Technology Transfer Document. National Integrated Research Program on Medicinal Plants; 1990:82-83.

23. De Leon-Pandanan AT, Dizon JA, Regalado-Morales E, Carpio BL. "Akapulko" cream: an effective alternative therapy for pityriasis versicolor in patients of the Ospital ng Maynila Medical Center Section of Dermatology. J Philipp Soc Cutan Med. 2002; 3(1):51-4.

24. Oladele AT, Elujoba AA, Oyelami AO. Clinical studies of three herbal soaps in the management of superficial fungal infections. Res J Med Plant. 2012; 6(1):56-64.

25. World Health Organization. WHO Model Prescribing Information: Drugs Used in Skin Diseases: Antifugal drugs: Sodium thiosulfate [Internet]. 1997[cited 2018 Jan]. Available from http://apps.who.int/ medicinedocs/en/d/Jh2918e/24.14.html\#Jh2918e.24.14.

26. Ilic L, Gowrishankar TR, Vaughan TE, Herndon TO, Weaver JC. Spatially constrained skin electroporation with sodium thiosulfate and urea creates transdermal microconduits. J Control Release [Internet]. 1999 [cited 2018 Jan];61(1-2):185-202. Available from http://www.ncbi.nlm.nih.gov/pubmed/10469915.

27. Seth SD. Textbook Of Pharmacology [Internet]. Elsevier India. 2009 [cited $2018 \mathrm{Jan}$ ]. Available from https://books.google.com/books?i $\mathrm{d}=51 \mathrm{ozlZRBvQwC} \& \mathrm{dq}=$ sodium + thiosulfate + fungistatic\&source $=\mathrm{g}$ bs_navlinks_s.

28. Kundu RV, Garg A. Yeast infections: candidiasis, tinea (pityriasis) versicolor, and Malassezia (pityrosporum) folliculitis. In: Goldsmith LA, Katz SI, Gilchrest BA, Paller AS, Leffell DJ, Wolff K, eds. Fitzpatrick's Dermatology in General Medicine, 8th ed. McGraw Hill Professional; 2012. p. 3190

29. American Academy of Dermatology. Tinea versicolor [Internet]. American Academy of Dermatology. 2017 [cited 2018 Jan]. Available from https://www.aad.org/public/diseases/color-problems/ tinea-versicolor\#treatment.

30. Damodaran S, Venkataraman S. A study on the therapeutic efficacy of Cassia alata, Linn. leaf extract against Pityriasis versicolor. J Ethnopharmacol. 1994; 42(1):19-23.

31. Oladele AT, Dairo BA, Elujoba AA, Oyelami AO. Management of superficial fungal infections with Senna alata ("alata") soap : A preliminary report. Afr J Pharm Pharmacol. 2010; 4:98-103. 


\section{APPENDICES}

Appendix 1. Characteristics of excluded studies

\begin{tabular}{ll}
\hline Study ID & Reason for exclusion \\
Damodaran $1994^{30}$ & Not an RCT \\
Oladele $2010^{31}$ & Comparator was placebo \\
\hline
\end{tabular}

Appendix 2. Characteristics of included studies

\begin{tabular}{|c|c|c|c|c|}
\hline Study ID & Participants & Intervention & Control & Outcome/s \\
\hline $\begin{array}{l}\text { Valdez-Eusebio, } \\
1990^{22}\end{array}$ & $\begin{array}{l}98 \text { patients with tinea } \\
\text { versicolor; dermatology } \\
\text { clinic; Philippines }\end{array}$ & $\begin{array}{l}\text { S. alata } 50 \% \text { lotion } \\
\text { BID for } 6 \text { wks. }\end{array}$ & $\begin{array}{l}\text { (+) Control: STS } 25 \% \text { lotion } \\
\text { (-) Control: placebo } \\
\text { BID for } 6 \text { wks. }\end{array}$ & $\begin{array}{l}\text { Mycologic cure on } \mathrm{KOH} \text { mount; } \\
\text { Clinical activity: scaling and } \\
\text { erythema were assessed separately; } \\
\text { Adverse effects }\end{array}$ \\
\hline $\begin{array}{l}\text { De Dios-Torralba, } \\
1993^{14}\end{array}$ & $\begin{array}{l}60 \text { patients with tinea } \\
\text { versicolor; dermatology } \\
\text { clinic; Philippines }\end{array}$ & $\begin{array}{l}\text { S. alata } 50 \% \text { lotion } \\
\text { BID for } 4 \text { wks. }\end{array}$ & $\begin{array}{l}\text { STS } 25 \% \text { lotion } \\
\text { BID for } 4 \text { wks. }\end{array}$ & $\begin{array}{l}\text { Mycologic cure on } \mathrm{KOH} \\
\text { mount; Clinical activity: scaling } \\
\text { and erythema were assessed } \\
\text { separately; Cure (negative } \mathrm{KOH} \\
\text { mount and disappearance of } \\
\text { scaling+erythema); Adverse effects }\end{array}$ \\
\hline Reyes, $1993^{11}$ & $\begin{array}{l}174 \text { patients with tinea } \\
\text { versicolor; dermatology } \\
\text { clinic, Philippines }\end{array}$ & $\begin{array}{l}\text { S. alata } 50 \% \text { lotion } \\
\text { BID for } 4 \text { wks. }\end{array}$ & $\begin{array}{l}\text { (+) Control: STS } 25 \% \text { solution } \\
\text { (-) Control: placebo } \\
\text { BID for } 4 \text { wks. }\end{array}$ & $\begin{array}{l}\text { Mycologic cure on } \mathrm{KOH} \text { mount; } \\
\text { Clinical activity: scaling and } \\
\text { erythema were assessed separately; } \\
\text { Adverse effects }\end{array}$ \\
\hline Dofitas, $2001^{10}$ & $\begin{array}{l}129 \text { patients with tinea } \\
\text { versicolor; dermatology } \\
\text { clinic, Philippines }\end{array}$ & $\begin{array}{l}\text { S. alata } 50 \% \text { lotion } \\
\text { BID for } 4 \text { wks. }\end{array}$ & $\begin{array}{l}\text { STS } 25 \% \text { lotion } \\
\text { BID for } 4 \text { wks. }\end{array}$ & $\begin{array}{l}\text { Mycologic cure on } \mathrm{KOH} \text { mount; } \\
\text { Clinical activity: scaling and } \\
\text { erythema were assessed separately; } \\
\text { Adverse effects }\end{array}$ \\
\hline $\begin{array}{l}\text { De Leon- } \\
\text { Pandanan, } 2002^{23}\end{array}$ & $\begin{array}{l}150 \text { patients with tinea } \\
\text { versicolor; dermatology } \\
\text { clinic, Philippines }\end{array}$ & $\begin{array}{l}\text { S. alata cream } \\
\text { BID for two wks. }\end{array}$ & $\begin{array}{l}\text { 1\% Terbinafine cream } \\
\text { BID for two wks. }\end{array}$ & $\begin{array}{l}\mathrm{KOH} \text { examination recorded as }(+) \\
\text { or }(-) \text { mycologic cure }\end{array}$ \\
\hline Ting, $2000^{13}$ & $\begin{array}{l}48 \text { patients with "cutaneous } \\
\text { fungal infection", } \\
\text { Upper Dicayas Relocation } \\
\text { Site, Dipolog City, } \\
\text { Zamboanga del Norte }\end{array}$ & $\begin{array}{l}\text { S. alata cream } \\
\text { Applied BID for } \\
15 \text { days }\end{array}$ & $\begin{array}{l}\text { Ketoconazole cream } \\
\text { Applied BID for } 15 \text { days }\end{array}$ & $\begin{array}{l}\text { Clinical resolution of lesions } \\
\text { (no clearing, partial clearing, } \\
\text { complete clearing); adverse } \\
\text { reaction; KOH smear }\end{array}$ \\
\hline Oladele, $2012^{24}$ & $\begin{array}{l}67 \text { patients with "superficial } \\
\text { fungal skin infections" } \\
\text { llesa Prison, Nigeria }\end{array}$ & $\begin{array}{l}\text { S. alata soap } \\
\text { Lather and bathe } \\
\text { with soap BID } \\
\text { for } 4 \text { wks. }\end{array}$ & $\begin{array}{l}\text { Control 1: Erythrophleum } 5 \% \\
\text { w/w soap } \\
\text { Control 2: Xylopia } 5 \% \text { w/w soap } \\
\text { Control 3: placebo soap } \\
\text { Lather and bathe with soap BID } \\
\text { for } 4 \text { wks. }\end{array}$ & $\begin{array}{l}\text { Did not specify any outcome } \\
\text { measure }\end{array}$ \\
\hline
\end{tabular}

STS - Sodium thiosulfate; BID - Twice daily 
Appendix 3. Summary of Findings Table 1

$50 \%$ Senna alata lotion compared to $25 \%$ Sodium Thiosulfate lotion for tinea versicolor

Patient or population: tinea versicolor

Setting: Dermatology clinic

Intervention: $50 \%$ Senna alata lotion

Comparison: $25 \%$ Sodium Thiosulfate lotion

\begin{tabular}{|c|c|c|c|c|c|c|}
\hline \multirow[b]{2}{*}{ Outcome } & \multicolumn{2}{|c|}{ Anticipated absolute effect* (95\% Cl) } & \multirow[b]{2}{*}{$\begin{array}{l}\text { Relative effect } \\
\text { (95\% Cl) }\end{array}$} & \multirow{2}{*}{$\begin{array}{c}\text { No. of } \\
\text { participants } \\
\text { (studies) }\end{array}$} & \multirow{2}{*}{$\begin{array}{l}\text { Certainty of } \\
\text { the evidence } \\
\text { (GRADE) }\end{array}$} & \multirow[b]{2}{*}{ Comments } \\
\hline & $\begin{array}{c}\text { Risk with } 25 \% \text { Sodium } \\
\text { Thiosulfate lotion }\end{array}$ & $\begin{array}{c}\text { Risk with } 50 \% \\
\text { Senna alata lotion }\end{array}$ & & & & \\
\hline $\begin{array}{l}\text { Mycologic Cure assessed with: } \\
\text { Potassium hydroxide (KOH) smear }\end{array}$ & 95 per 100 & $\begin{array}{l}86 \text { per } 100 \\
(75 \text { to } 99)\end{array}$ & $\begin{array}{c}\text { RR } 0.91 \\
\text { (0.79 to } 1.04)\end{array}$ & $\begin{array}{c}216 \\
(4 \mathrm{RCTs})^{1,2,3,4}\end{array}$ & $\begin{array}{l}\oplus \oplus \bigcirc \bigcirc \\
\mathrm{LOW}\end{array}$ & \\
\hline Adverse Effects & 9 per 100 & $\begin{array}{c}11 \text { per } 100 \\
\text { (4 to } 31)\end{array}$ & $\begin{array}{c}\text { RR } 1.26 \\
\text { (0.46 to } 3.44)\end{array}$ & $\begin{array}{c}120 \\
(2 \text { RCTs })^{1,3}\end{array}$ & $\begin{array}{c}\bigoplus O_{\text {VERY LOW }}^{c, d} \\
\text { VER }\end{array}$ & \\
\hline Clinical Cure & 90 per 100 & $\begin{array}{l}57 \text { per } 100 \\
(36 \text { to } 89)\end{array}$ & $\begin{array}{c}\text { RR } 0.63 \\
\text { (0.40 to } 0.99) \\
\end{array}$ & $\begin{array}{c}36 \\
(1 \mathrm{RCT})^{4} \\
\end{array}$ & $\begin{array}{l}\bigoplus \bigoplus{ }_{\text {LOW }} \\
\text { 4,e,f }\end{array}$ & \\
\hline
\end{tabular}

${ }^{*}$ The risk in the intervention group (and its $95 \%$ confidence interval) is based on the assumed risk in the comparison group and the relative effect of the intervention (and its $95 \% \mathrm{Cl}$ ).

$\mathrm{Cl}$ : Confidence interval; RR: Risk ratio

GRADE Working Group grades of evidence

High certainty: We are very confident that the true effect lies close to that of the estimate of the effect

Moderate certainty: We are moderately confident in the effect estimate: The true effect is likely to be close to the estimate of the effect, but there is a possibility that it is substantially different

Low certainty: Our confidence in the effect estimate is limited: The true effect may be substantially different from the estimate of the effect Very low certainty: We have very little confidence in the effect estimate: The true effect is likely to be substantially different from the estimate of effect Explanations:

a. High risk for attrition bias. Sensitivity analyses revealed a soft conclusion for three studies. One study did not indicate number of dropouts per treatment arm.

b. High heterogeneity due to one study with longer treatment period and significant number of dropouts.

c. Sensitivity analysis of one study reveals a soft conclusion, while another study only indicated the number of participants who completed the trial, hence a sensitivity analysis cannot be performed.

d. Confidence intervals are very wide and crossed both significant benefit $(R R>1.25)$ and harm $(R R<0.75)$.

e. High risk for attrition bias. Sensitivity analysis reveals a soft conclusion.

f. Confidence interval is wide and crossed harm $(R R<0.75)$.

1. De Dios-Torralba, 1993

2. Reyes, 1996

3. Dofitas, 2001

4. Valdez-Eusebio, 1996 
Appendix 3. Summary of Findings Table 2

\begin{tabular}{|c|c|c|c|c|c|c|}
\hline \multicolumn{7}{|c|}{ Senna alata cream compared to Ketoconazole cream for tinea versicolor } \\
\hline \multicolumn{7}{|c|}{$\begin{array}{l}\text { Patient or population: tinea versicolor } \\
\text { Setting: Dermatology clinic } \\
\text { Intervention: Senna alata cream } \\
\text { Comparison: Ketoconazole cream }\end{array}$} \\
\hline \multirow[b]{2}{*}{ Outcome } & \multicolumn{2}{|c|}{ Anticipated absolute effect $(95 \% \mathrm{CI})$} & \multirow[b]{2}{*}{$\begin{array}{l}\text { Relative effect } \\
\qquad(95 \% \mathrm{CI})\end{array}$} & \multirow{2}{*}{$\begin{array}{l}\text { No. of } \\
\text { participants } \\
\text { (studies) }\end{array}$} & \multirow{2}{*}{$\begin{array}{l}\text { Certainty of } \\
\text { the evidence } \\
\text { (GRADE) }\end{array}$} & \multirow[b]{2}{*}{ Comments } \\
\hline & $\begin{array}{c}\text { Risk with } \\
\text { Ketoconazole cream }\end{array}$ & $\begin{array}{c}\text { Risk with } \\
\text { Senna alata cream }\end{array}$ & & & & \\
\hline Mycologic Cure & 100 per 100 & $\begin{array}{l}95 \text { per } 100 \\
(82 \text { to } 100)\end{array}$ & $\begin{array}{c}\text { RR } 0.95 \\
\text { (0.82 to } 1.09) \\
\end{array}$ & $\begin{array}{c}40 \\
(1 \mathrm{RCT})^{1}\end{array}$ & $\underset{\text { HIGH }}{\bigoplus \bigoplus \bigoplus \bigoplus}$ & \\
\hline Clinical Cure & 5 per 100 & $\begin{array}{l}2 \text { per } 100 \\
(0 \text { to } 40)\end{array}$ & $\begin{array}{c}\text { RR } 0.37 \\
(0.02 \text { to } 8.50)\end{array}$ & $\begin{array}{c}40 \\
(1 \mathrm{RCT})^{1}\end{array}$ & $\underset{\text { LOW }^{\text {a }}}{\bigoplus}$ & \\
\hline
\end{tabular}

${ }^{*}$ The risk in the intervention group (and its $95 \%$ confidence interval) is based on the assumed risk in the comparison group and the relative effect of the intervention (and its $95 \% \mathrm{Cl}$ ).

Cl: Confidence interval; RR: Risk ratio

GRADE Working Group grades of evidence

High certainty: We are very confident that the true effect lies close to that of the estimate of the effect

Moderate certainty: We are moderately confident in the effect estimate: The true effect is likely to be close to the estimate of the effect, but there is a possibility that it is substantially different

Low certainty: Our confidence in the effect estimate is limited: The true effect may be substantially different from the estimate of the effect Very low certainty: We have very little confidence in the effect estimate: The true effect is likely to be substantially different from the estimate of effect

Explanations:

a. Confidence intervals are very wide and crossed both significant benefit $(R R>1.25)$ and harm $(R R<0.75)$.

1. Ting. 2000

Appendix 3. Summary of Findings Table 3

Senna alata cream compared to $1 \%$ Terbinafine cream for dermatophytosis or tinea versicolor

Patient or population: dermatophytosis or tinea versicolor

Setting: Dermatology clinic

Intervention: Senna alata cream

Comparison: $1 \%$ Terbinafine cream

\begin{tabular}{|c|c|c|c|c|c|c|}
\hline \multirow[b]{2}{*}{ Outcome } & \multicolumn{2}{|c|}{ Anticipated absolute effect $(95 \% \mathrm{Cl})$} & \multirow{2}{*}{$\begin{array}{l}\text { Relative effect } \\
\quad(95 \% \mathrm{CI})\end{array}$} & \multirow{2}{*}{$\begin{array}{l}\text { No. of } \\
\text { participants } \\
\text { (studies) }\end{array}$} & \multirow{2}{*}{$\begin{array}{l}\text { Certainty of } \\
\text { the evidence } \\
\text { (GRADE) }\end{array}$} & \multirow[b]{2}{*}{ Comments } \\
\hline & $\begin{array}{c}\text { Risk with } 1 \% \\
\text { Terbinafine cream }\end{array}$ & $\begin{array}{c}\text { Risk with } \\
\text { Senna alata cream }\end{array}$ & & & & \\
\hline Mycologic Cure & 97 per 100 & $\begin{array}{l}91 \text { per } 100 \\
\text { (84 to } 98)\end{array}$ & $\begin{array}{c}\text { RR } 0.93 \\
\text { (0.86 to } 1.01)\end{array}$ & $\begin{array}{c}150 \\
(1 \mathrm{RCT})^{1}\end{array}$ & 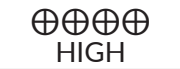 & \\
\hline
\end{tabular}

${ }^{*}$ The risk in the intervention group (and its $95 \%$ confidence interval) is based on the assumed risk in the comparison group and the relative effect of the intervention (and its $95 \% \mathrm{Cl}$ ).

Cl: Confidence interval; RR: Risk ratio

GRADE Working Group grades of evidence

High certainty: We are very confident that the true effect lies close to that of the estimate of the effect

Moderate certainty: We are moderately confident in the effect estimate: The true effect is likely to be close to the estimate of the effect, but there is a possibility that it is substantially different

Low certainty: Our confidence in the effect estimate is limited: The true effect may be substantially different from the estimate of the effect Very low certainty: We have very little confidence in the effect estimate: The true effect is likely to be substantially different from the estimate of effect Explanations:

1. De Leon-Pandanan, 2002 